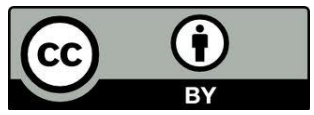

\title{
A prática de Ensino Religioso não confessional nas abordagens da Revista Diálogo
}

\author{
The practice of non-confessional religious education in the approaches of Dialogue \\ Magazine
}

\author{
Roseane do Socorro Gomes Barbosa \\ Mestra em Ciências da Religião pela Pontifícia Universidade Católica de São Paulo. \\ roseanegbarbosa@yahoo.com.br
}

\begin{abstract}
RESUMO: O Ensino Religioso escolar não é um elemento estranho, pois ele sempre fez parte da educação brasileira, inicialmente como o elemento de religião na escola, e atualmente como o estudo das religiões enquanto manifestações culturais. Partindo do pressuposto que o papel do Ensino Religioso no ambiente escolar tem por objetivo o estuda da religião como uma área de conhecimento, tal como a geografia, a história, a matemática etc., nos propomos a analisar a disciplina nessa perspectiva, e tomamos como referência para a nossa análise as abordagens da Diálogo - Revista de Ensino Religioso. O nosso objetivo neste artigo é demonstrar que a prática de Ensino Religioso não confessional é possível desde que ela esteja alicerçada em uma área de conhecimento que conceda ao Ensino Religioso um referencial teórico e epistemológico adequados. Desse modo, a área que melhor responde a essa finalidade são as Ciências da Religião, justamente pelo fato de ter a religião, em suas deferentes perspectivas, como o principal objeto de estudo. Nesse sentido é interessante ressaltar que no âmbito escolar a religião é um dado a ser conhecido que não pressupõe a fé, pois do contrário é proselitismo.

Palavras-chave: Revista Diálogo, Ensino Religioso, Ciências da Religião
\end{abstract}

ABSTRACT: Religious Education school is not a foreign element, as it has always been part of Brazilian education, initially as the element of religion in school, and currently as the study of religions as cultural manifestations. Assuming the role of Religious Education in the school aims to study religion as a field of knowledge, such as geography, history, mathematics etc., We propose to examine the subject from this perspective, and as we reference for our analysis approaches of Dialogue - Journal of Religious Education. Our goal in this article is to demonstrate that the practice of non-confessional religious education is possible since it is grounded in a knowledge area that gives the Religious Education a theoretical and epistemological appropriate. Thus, the area that is best suited to this purpose is the Science of Religion, precisely because you have religion in their deferent perspectives, as the main object of study. In this sense it is interesting to note that in schools religion is a given to be known that not presuppose faith, otherwise is proselytizing.

Keywords: Dialogue Magazine, Religious Education, Religious Studies 


\section{Introdução}

O Ensino Religioso no contexto escolar não é um elemento estranho, pois ele sempre fez parte da educação brasileira, inicialmente como o elemento de religião na escola, e atualmente como o estudo das religiões enquanto manifestações culturais.

Alguns pesquisadores e grupos ligados à educação discutem acerca da permanência do Ensino Religioso na grade curricular, entretanto a questão prioritária que se coloca no momento se relaciona ao conteúdo prático e programático de tal disciplina. Essa questão ao mesmo tempo é o centro de muitas discursões, pois durante certo tempo a prática do Ensino Religioso no ambiente aproximava-se mais da catequese, do que propriamente da educação. Dessa prática decorre a rejeição ao modelo confessional, entretanto é preciso considerar que esta não é a única forma de ministrar o conteúdo do Ensino Religioso que visa o estudo da religião e não sua doutrinação.

Partindo do pressuposto que o papel do Ensino Religioso no ambiente escolar tem por objetivo o estuda da religião como uma área de conhecimento, tal como a geografia, a história, a matemática etc., nos propomos a analisar a disciplina de Ensino Religioso com essa perspectiva, e tomamos como referência para a nossa análise as abordagens da Diálogo - Revista de Ensino Religioso.

A Diálogo é um periódico que busca subsidiar os professores de Ensino Religioso, tanto em sua prática pedagógica, quanto em sua formação. Embora a revista seja uma publicação de uma editora cristã católica, desde a sua primeira edição, ela sempre buscou apresentar o Ensino Religioso desvinculado de qualquer religião e voltado para a educação.

O nosso objetivo neste artigo é demonstrar que a prática de Ensino Religioso não confessional é possível desde que ela esteja alicerçada em uma área de conhecimento que conceda ao Ensino Religioso um referencial teórico e epistemológico adequados. Desse modo, a área que melhor responde a essa finalidade são as Ciências da Religião, justamente pelo fato de ter a religião, em suas deferentes perspectivas, como o principal objeto de estudo. Nesse sentido é interessante ressaltar que no âmbito escolar a religião é um dado a ser conhecido que não pressupõe a fé, pois do contrário é proselitismo.

\section{A tessitura do Ensino Religioso}

Constamos no contexto brasileiro atual acerca do Ensino Religioso diferente posicionamentos, favoráveis e também contrários, a esse componente curricular, cujo objeto de estudo é a religião. É importante ressaltar que o termo religião, se constitui em um conceito bastante complexo de se definir, pois, segundo Greschat, não há uma definição universal de religião, e sim uma polissemia de sentido, de modo que este pode variar conforme o que o interlocutor tem em mente (GRESCHAT, 2006). Nesse sentido, a discussão não é tão simples, ainda mais quando tratamos de um elemento que compõe a formação do cidadão e que não goza das mesmas condições que os demais componentes curriculares.

Algumas questões surgem no bojo da discussão: Como entender a natureza de um ensino que é obrigatório para a escola e facultativo quanto à adesão do aluno? (LDB 9475/97) O que se pode entender por religioso no âmbito da escola? Como definir o conteúdo de uma disciplina que trata de uma categoria tão complexa como é a 
religião? As indagações que surgem são muitas, e todas necessitariam de uma resposta; entretanto não temos a pretensão de responder a todas as questões que surgem.

É importante ressaltar que o Ensino Religioso não é um elemento estranho como componente da educação; pelo contrário, ele sempre esteve presente na educação brasileira, e, segundo Oliveira, desde o período da colonização, quando "coube aos representantes eclesiásticos da Companhia de Jesus, por delegação da Coroa Portuguesa, a 'educação' dos habitantes do território em processo de conquista, pelo exercício da catequese e instrução" (OLIVEIRA, 2003, p. 30), a educação religiosa passou a integrar a educação e permanece até os dias atuais como parte integrante da formação do cidadão brasileiro. É, sobretudo, no processo de escolarização do Ensino Religioso (JUNQUEIRA, 2000) que se destaca a sua ambivalência, pois este ora foi um elemento da religião no âmbito escolar, ora foi considerado área de conhecimento independente de uma religião específica, contudo, afirma Cortella, que não devemos confundir educação religiosa com Ensino Religioso, pois estes subentendem processos de socialização diferentes (CORTELA, 2006, p. 11-20).

Quando no Brasil o assunto é Ensino Religioso, logo vem à mente o catolicismo e Gruen afirma que, numa linguagem filosófica, o catolicismo é uma chave indispensável de interpretação da cultura brasileira, que ele chama de "espaço hermenêutico", pois a interpretação que o catolicismo provoca não é a mesma no protestante, espírita ou católico, contudo, é inevitável que todos eles se deparem com o catolicismo ao interpretar a própria realidade (GRUEN, 1995, p. 111-112). Essa associação não é equivocada, pois, uma vez que a Igreja Católica sempre postulou a presença do Ensino Religioso nos documentos oficiais do Brasil, é natural que o velho fantasma da cristandade volte a assombrar o pensamento das pessoas contrárias ao Ensino Religioso como componente curricular e preocupadas com a educação brasileira. Entretanto, a própria Igreja Católica no Brasil, também repensou a sua compreensão sobre o Ensino Religioso, passando este a ser entendido como algo distinto da catequese. Atenta às mudanças que vinham ocorrendo na educação, na legislação e na organização do Ensino Religioso em cada estado, a Conferência Nacional dos Bispos do Brasil (CNBB) percebeu que tal ensino se ligava mais à "educação integral, como disciplina do currículo escolar, do que ao universo da catequese, entendida como educação da fé, numa comunidade eclesial" (CNBB, 1999, p. 12-13).

Não podemos esquecer que a CNBB, a partir de 1984, promoveu e articulou, nos estados e em seu regionais, os Encontros Nacionais para Coordenadores de Ensino Religioso (ENER), realizados a cada dois anos, possibilitando a reflexão e a articulação, em todo o Brasil, de professores e pessoas interessados na discussão sobre o Ensino Religioso. Esses encontros foram importantes, tanto na trajetória de instalação do Fórum Nacional Permanente de Ensino Religioso (Fonaper), em 1997, quanto para a criação da Diálogo - Revista de Ensino Religioso, surgida a partir desses encontros.

É interessante ressaltar que o componente curricular Ensino Religioso foi reconhecido como área de conhecimento pelo Conselho Nacional de Educação (CNE), por meio da Resolução 02/98, em seu artigo 3', item IV, em 1988 (MENEGHUETTI, 2006, p. 137-143), porém ainda causa opiniões divergentes tanto em relação à sua liceidade, quanto à natureza de seus conteúdos. E mais ainda a disciplina não dispõe de parâmetros curriculares oficiais, isto é, do Ministério da Educação e Cultura, o que concederia ao Ensino Religioso um conteúdo programático e unificado, de modo que de norte a sul do Brasil haveria consenso e entendimento acerca dessa disciplina. 


\section{Os modelos de Ensino Religioso presente na educação brasileira}

Entre os argumentos contrários à presença no currículo encontra-se o fato de o ensino confessional se torna uma ameaça ao pluralismo religioso existente no Brasil. Entretanto, vale lembrar que o Ensino Religioso "não é mais de domínio desta ou daquela Igreja. É de domínio da sociedade, é dos educadores, enquanto profissionais deste ensino" (CNBB, 1999, p. 34).

É preciso considerar que os diferentes posicionamentos acerca do Ensino Religioso, se formaram ou mesmo se consolidaram dentro de um processo aparentemente evolutivo (JUNQUEIRA, 2000), que se iniciou efetivamente, em termos legais e educacionais no Brasil Império, e continuou durante todo o período republicano.

Ao revisitar o longo processo de desenvolvimento da educação no Brasil, é possível perceber que o Ensino Religioso também passou por grandes e significativas transformações, de modo a delinear diferentes compreensões sobre a natureza de seu conteúdo a partir da legislação, como evidencia a síntese da tabela a seguir sistematizada a partir da tese de doutorado Sérgio Junqueira (JUNQUEIRA, 2000).

Tabela 1: Esquematização de Sérgio Junqueira

\begin{tabular}{c|lll}
\hline Lei n. & \multicolumn{1}{c}{ Proposta } & \multicolumn{1}{c}{ Perspectiva } & \multicolumn{1}{c}{ Referencial } \\
\hline $\mathbf{4 . 0 2 4 / 6 1}$ & Confessional & $\begin{array}{l}\text { Uma confissão religiosa } \\
\text { (católica) }\end{array}$ & A doutrina católica \\
$\mathbf{5 . 6 9 2 / 7 1}$ & Interconfessional & Diferentes confissões cristãs & $\begin{array}{l}\text { O que há em comum no cristianismo } \\
\text { As ciências humanas (fenomenologia, } \\
\text { antropologia entre outras) }\end{array}$ \\
\hline
\end{tabular}

João Décio Passos também sistematizou essas diferentes concepções de Ensino Religioso e as classificou sob a categoria de "modelos" de ensino (PASSOS, 2007). Passos afirma que tal classificação pretende "captar e remeter para as concepções e práticas concretas dessa disciplina" (PASSOS, 2007, p. 52).

Entende-se, grosso modo, a proposta de Passos da seguinte forma: o primeiro modelo é o catequético, que tem como pano de fundo o proselitismo, isto é, o ensinamento de uma determinada doutrina. É o modelo mais antigo e se relaciona ao contexto em que a religião era hegemônica na sociedade. O segundo modelo é o teológico, que segue uma perspectiva ecumênica e cujo objetivo é promover o diálogo entre as religiões cristãs e se fundamenta numa sociedade plural e secularizada com bases antropológicas. E, por fim, tem-se o modelo das Ciências da Religião, que também é chamado por outros autores de fenomenológico. Esse modelo não está vinculado a nenhuma religião específica, e sua abordagem segue uma perspectiva antropológica e sociocultural, que recebe das Ciências da Religião o seu referencial teórico e metodológico para o estudo e o ensino da religião (PASSOS, 2007, p. 50-68).

Para chegar a esses modelos, Passos os analisa a partir de oito aspectos que oferecem uma visão sinótica e comparativa dos mesmos. Os pontos escolhidos por Passos para a leitura paralela são: cosmovisão, contexto político, fonte, método, afinidade, objetivo, responsabilidade e riscos. Postos os três modelos lado a lado é possível perceber claramente suas principais diferenças e objetivos, o que favorece uma visão sistêmica dos mesmos que aqui reproduzimos e adaptamos para melhor visualizar o esquema proposto. E destacamos os riscos que cada um dos modelos, possivelmente, pode representar ao Ensino Religioso. 
Tabela 2: Esquematização de João Décio Passos

\begin{tabular}{|c|c|c|c|}
\hline Aspectos & $\begin{array}{c}\text { Modelo } \\
\text { Catequético }\end{array}$ & $\begin{array}{c}\text { Modelo } \\
\text { Teológico } \\
\end{array}$ & $\begin{array}{c}\text { Modelo das } \\
\text { Ciências da Religião }\end{array}$ \\
\hline Cosmovisão & Unirreligiosa & Plurirreligiosa & Transreligiosa \\
\hline Contexto político & $\begin{array}{l}\text { Aliança Igreja- } \\
\text { Estado }\end{array}$ & Sociedade secularizada & Sociedade secularizada \\
\hline Fonte & Conteúdos doutrinais & $\begin{array}{l}\text { Antropologia, teologia do } \\
\text { pluralismo }\end{array}$ & Ciências da Religião \\
\hline Método & Doutrinação & Indução & Indução \\
\hline Afinidade & Escola tradicional & Escola nova & Epistemologia atual \\
\hline Objetivo & Expansão das Igrejas & Formação religiosa dos cristãos & Educação do cidadão \\
\hline Responsabilidade & Confissões religiosas & Confissões religiosas & $\begin{array}{c}\text { Comunidade científica e do } \\
\text { Estado }\end{array}$ \\
\hline Riscos & $\begin{array}{l}\text { Proselitismo } \\
\text { e intolerância }\end{array}$ & $\begin{array}{l}\text { Catequese } \\
\text { disfarçada }\end{array}$ & $\begin{array}{l}\text { Neutralidade } \\
\text { científica }\end{array}$ \\
\hline
\end{tabular}

Toda área de conhecimento apresenta riscos, pois nenhuma ciência ou conhecimento é neutro. Podemos afirmar que o Ensino Religioso não é neutro, e nem o deve ser, assim como também não deve ser tendencioso seguindo por uma linha confessional. A sua relevância "advém da importância social da religião como um dado humano que se mostra nas múltiplas dimensões humanas (social, cultural, política, psicológica etc.), nas ações humanas e nas instituições sociais de ontem e de hoje" (PASSOS, 2007, p. 94). O Ensino Religioso "tem que estar inserido na nossa realidade, na experiência social do aluno" (GRUEN, 1995, p. 119), de modo a conduzi-lo "à ação e ao engajamento que ocorrem num fluxo de valorações e opções que envolvem o indivíduo e a sociedade" (PASSOS, 2007, p. 77).

É nesse sentido que se afirma a não neutralidade do Ensino Religioso. Nesse componente curricular há um telos, que é fazer com que o educando se engaje não numa comunidade de fé, e sim na sociedade, de um modo mais participativo e consciente de seus valores, direitos e deveres.

\section{O Ensino Religioso expresso na linguagem de uma Revista}

Os Ener exerceram grande importância na caminhada do Ensino Religioso no Brasil e também na criação da revista Diálogo.

\footnotetext{
Em agosto de 1994, em Fortaleza (CE), realizou-se o $10^{\circ}$ Ener - com a participação de 180 professores de 23 estados - tendo como tema central: O Fenômeno Religioso na pós-modernidade: Mudanças socioculturais, manifestações religiosas e o diálogo inter-religioso. Nas propostas de encerramento do encontro, os professores manifestaram o desejo e a urgência de se criar uma revista de Ensino Religioso que os ajudasse na formação profissional específica e fosse, ao mesmo tempo, um elo de comunicação, intercâmbio de experiências e informações entre os professores de várias regiões do País (SENA, in Diálogo, n. 39, 2005, p. 46).
}

A Diálogo - Revista de Ensino Religioso resultou dos esforços de muitas pessoas que acreditaram na força do Ensino Religioso. E entre as pessoas que impulsionaram a criação da revista está Dom Aloysio Leal Penna, "bispo então responsável pelo Setor de Educação da CNBB, que, catalizando os anseios dos 
professores, procurou viabilizar a proposta da revista" (REVISTA DIÁLOGO, 1995, n. 0, p. 1).

Em 26 de setembro de 1995, foi lançada oficialmente a edição de número zero da Diálogo, durante um encontro em Santa Catarina.

\begin{abstract}
Por ocasião da 29a Assembleia Ordinária do Conselho de Igrejas para a Educação Religiosa (Cier), que comemorava 25 anos de existência, realizouse a instalação do Fórum Nacional Permanente do Ensino Religioso e o lançamento do primeiro número da revista, que recebeu o nome de Diálogo Revista de Ensino Religioso. O evento ocorreu no hotel Itaguaçu, em Florianópolis (SC), e contou com a presença de representantes de entidades educacionais e religiosas e de professores de vários estados do Brasil (SENA; CARNIATO, 2010, p. 180).
\end{abstract}

A revista de cunho monotemático, desde a sua primeira edição apresentava um tema principal, indicado na chamada de capa, e abordado em diferentes perspectivas. Estruturalmente a revista intercalava textos-artigos de fundamentação teórica com textos para serem usados pelo professor em sala de aula, tais como contos, poesias, parábolas etc.

Ao se voltar para as discussões que envolvem a escola de um modo geral, como, por exemplo, o multiculturalismo ou questões étnicas, a revista evidencia que o Ensino Religioso como componente curricular não está centrado apenas em temas acerca da cultura religiosa, pelo contrário, a sua presença é multi ou transdisciplinar.

Embora os textos dos artigos sejam curtos, de cinco a seis laudas, eles buscam levantar os pontos principais em relação ao tema proposto, sem a preocupação de dar conta de responder a todas as questões acerca do assunto. A intenção é oferecer as condições para que o professor se interesse pelo tema proposto e, a partir das provocações levantadas pelo texto, busque aprofundá-lo e reflita sobre como aplicá-lo em sua prática docente.

\title{
As Ciências da Religião como fundamento teórico do Ensino Religioso
}

A proposta confessional, e também a interconfessional ou ecumênica, do Ensino Religioso toma como fundamentação teórica a doutrina de uma determinada Igreja, e sua teologia, seus valores e sua moral se constituem em conteúdo ministrado em sala de aula. Na realidade, tal proposta não configura o Ensino Religioso e sim uma catequese ministrada no âmbito escolar.

Para não recair na limitação de um ensino catequético, o Ensino Religioso necessita buscar a sua base teórica e metodológica numa "tradição" científica, pois "o Ensino Religioso como tarefa epistemológica remete sua fundamentação para o âmbito das ciências e de seu ensino" (PASSOS, 2006, p. 24) e não para as confissões religiosas. Segundo Soares, a desvinculação da confessionalidade é precondição para que o Ensino 
Religioso possa se servir das Ciências da Religião como área de conhecimento (SOARES, 2010, 119).

O Ensino Religioso ao se fundamentar teórica e metodologicamente nas Ciências da Religião, como afirma Soares, torna-se a transposição didática do conhecimento produzido por essa área para as aulas no ensino fundamental e também no médio (SOARES, 2010, 118). Dessa mesma base epistemológica, que são as Ciências da Religião, também advém o objeto de estudo do Ensino Religioso, que é o Fenômeno Religioso com toda a sua complexidade (TEIXEIRA, 2006, p. 65) e diversidade de abordagens.

As Ciências da Religião também podem contribuir na possibilidade de comparar diferentes sistemas de referências (Apud USARSK, 2006, p. 58), bem como numa "análise diacrônica e sincrônica do Fenômeno Religioso, a saber, o aprofundamento das questões de fundo da experiência e das expressões religiosas, a exposição panorâmica das tradições religiosas e as suas correlações socioculturais" (SOARES, 2012, p. 88).

É importante lembrar que o modelo de Ensino Religioso sob a perspectiva das Ciências da Religião não está isento de riscos, como apontamos na esquematização de modelos propostos por Passos e apresentados no capítulo I deste trabalho. Entretanto, como afirma Soares, "educar é transmitir conhecimentos e valores, algo muito distante da atitude de quem vive em cima do muro" (Apud USARSK, 2006, p. 97). Passos também afirma que:

Esse modelo [das Ciências da Religião] não afirma o ensino da religião como uma atividade científica neutra, mas com clara intencionalidade educativa postula a importância do conhecimento da religião para a vida ética e social dos educandos (PASSOS, 2006, p. 32).

O pressuposto que o Ensino Religioso recebe das Ciências da Religião, segundo Passos, é a educação do cidadão, pois o objetivo do estudo das religiões dentro da escola não difere das demais disciplinas que têm em vista a cidadania.

O conhecimento da religiosidade e da religião faz parte do processo educacional, assim como o conhecimento da Matemática, da História, da Política etc. A religião não é coisa tão somente das instituições confessionais, ela é um fato antropológico e social que permeia de maneira ativa todos os âmbitos da vida dos cidadãos que compõem o Estado plural e laico. Eis a razão fundamental de seu estudo nas escolas (PASSOS, 2006, p. 36).

Ao se pensar a formação básica do cidadão, não se pode subtrair nenhuma de suas dimensões humanas, pois a educação atinge o indivíduo em sua integralidade. E mesmo entre aquele que não professam nenhuma religião, ou se declaram agnósticos ou ateus, se justifica excluir o estudo das religiões, pois independentemente de o indivíduo reconhecê-la ou não, essa dimensão está presente no ser humano. É interessante ressaltar que a religião também é "um dado antropológico e sociocultural que tem força de fundamentar as ações mais conservadoras ou transformadoras, mais perversas ou benéficas" (PASSOS, 2006, p. 41), como afirma Passos. Além de ser um elemento presente em várias sociedades, a religião também produz um conhecimento que, como tal, se torna patrimônio da humanidade, e que necessita estar disponível a todos (FONAPER, 1997, p. 35). Passos também afirma que:

O estudo científico das religiões é tão laico quanto qualquer outro inscrito na esfera das ciências que são usadas nas escolas, o que não significa que todo ensino não traga em seus objetivos a formação de valores nos educandos. Toda ciência é ensinada com finalidades pedagógicas e tem, portanto, crenças embutidas em suas programações; e toda educação não é uma reprodução de 
princípios e métodos neutros, mas de valores a serem assimilados pelos educandos (PASSOS, 2006, p. 23).

É importante ressaltar que o conhecimento religioso dentro da escola tem a finalidade de ser conhecido e não afirmado como verdade de fé, (PASSOS, 2007) pois, do ponto de vista didático, o Ensino Religioso "não conta com a fé como ponto de partida, nem mesmo ousa propor a fé como objetivo, pois a fé explícita, assim como deve ser excluída, não pode ser programada" (GRUEN, 1995, 37).

Se o estudo da religião não parte da fé (como na Teologia), logo o seu referencial teórico necessita ser mais amplo, "capaz de abarcar as diversidades e, ao mesmo tempo, captar a singularidade que caracteriza" (PASSOS, 2006, p. 32) as religiões enquanto fenômeno a ser conhecido. Desse modo, o referencial apropriado ao Ensino Religioso é o das Ciências da Religião.

\section{O modelo das Ciências da Religião presente na Revista Diálogo}

Desde a primeira edição, a Diálogo buscou compreender que o Ensino Religioso é um importante componente curricular, pois visa a ajudar a formar no cidadão um novo ethos aberto ao respeito e à diversidade social, política e religiosa presente na educação brasileira. Conforme Oliveira,

Uma das muitas diferenças presentes no contexto educacional está relacionada com a questão religiosa, originada na diversidade cultural própria dos diferentes grupos de humanos. Ela envolve toda uma gama de relações, interações e conexões, associada a outras questões, que movem, facilitam ou emperram o processo educativo como um todo (OLIVEIRA, 2003, p. 173).

A concepção de um Ensino Religioso na ótica da diversidade e pluralidade

religiosa também se encontra na revista desde a sua primeira edição, como é possível perceber no editorial da edição n. 0 :

\footnotetext{
No contexto pluralista em que vivemos, a escola é o lugar de diálogo. O Ensino Religioso constitui, na escola, espaço importante no processo de aprendizagem da convivência humana, respeitosa, solidária, aberta ao outro, ao diferente. Colocados comunitária e pessoalmente em face do que dá sentido à vida, educandos e educadores aprendem a compartilhar suas alegrias, preocupações, lutas e experiências em busca do absoluto, unem-se na procura de respostas aos grandes desafios da vida e descobrem caminhos para se empenharem na construção de um mundo mais humano, mais justo e fraterno (DIÁLOGO, 1995, n. 0, p. 1).

Constata-se que a revista está voltada para o Ensino Religioso à luz das
}

Ciências da Religião, sobretudo no que diz respeito ao seu método de abordar os temas.

E assim como o Ensino Religioso busca nas Ciências da Religião a sua base

epistemológica, ela passa a se constituir o fundamento para todos aqueles que lidam com o Ensino Religioso dentro e/ou fora da sala de aula,

As Ciências da Religião, ao se constituírem como uma das bases epistemológicas para o Ensino Religioso, contribuíram para a compreensão do humano enquanto ser, aberto à transcendência e histórico-culturalmente situado dentro de referências religiosas, influenciadas por elas de múltiplas maneiras e, muitas vezes, agindo a partir delas (JUNQUEIRA, 2011, p.59). 
Quando alicerçado nas Ciências da Religião, o Ensino Religioso recebe delas as suas bases "teóricas e metodológicas para o estudo e o ensino da religião como disciplina autônoma e plenamente inserida nos currículos escolares" (PASSOS, 2007, p. 54). Entretanto, sabemos que ainda há um longo caminho a ser percorrido até que o modelo das Ciências da Religião seja consolidado, pois, segundo Passos: A adoção das Ciências da Religião como base epistemológica desse ensino
não parece ser um processo simples de ser concretizado, tendo em vista as
práticas já consolidadas e o jogo de interesses políticos das Igrejas em suas
relações com as conjunturas governamentais concretas (PASSOS, 2007, p.
55). constituinte do perfil da revista, é possível depreender de suas abordagens uma grande afinidade a esse modelo, além de agregar a este um elemento que é próprio da Diálogo, isto é, a sua abordagem monotemática dos temas.

A estrutura metodológica, monotemática da revista permite uma visão ampla do tema, a partir de diferentes perspectivas de abordagens, tanto do ponto de vista das diversas áreas do conhecimento, como antropologia, sociologia, história, psicologia, pedagogia, entre outras, como das diferentes tradições religiosas: hinduísmo, judaísmo, budismo, cristianismo, islamismo, bahá'í, candomblé, umbanda, xamanismo, tradições religiosas indígenas e outras expressões do Fenômeno Religioso contemporâneo (SENA; CARNIATO, 2010, p. 185).

Não podemos nos esquecer de que o modelo de Ensino Religioso cuja base epistemológica é a das Ciências da Religião ainda é algo em construção (PASSOS, 2007), e muitas discussões giram em torno desse eixo. Ademais, esse modelo é pouco conhecido, sobretudo por parte daqueles que se opõem ao Ensino Religioso como componente curricular, ou mesmo daqueles que dirigem duras críticas à liceidade $\mathrm{e}$ permanência do Ensino Religioso escolar.

Enfim, na análise das chamadas de capa, percebe-se que um modelo muito afinado com as Ciências da Religião se faz presente na revista. Entretanto, vale lembrar que a estruturação do Ensino Religioso em modelos é uma questão metodológica de diferenciar a aplicação do conteúdo do Ensino Religioso. E, embora a revista priorize a base epistemológica das Ciências da Religião em sua forma de abordagem, isso não significa que os outros modelos ou enfoques não possam ser detectados na Diálogo.

\section{O Ensino Religioso nas abordagens da Revista Diálogo}

Analisaremos dois exemplares da revista Diálogo, escolhidos por meio de sorteio, a fim de evidenciarmos como o Ensino Religioso se apresenta nas páginas da revista, bem como percebermos o enfoque de suas abordagens e o modelo de Ensino 
Religioso nela presente. Os números analisados são: o n. 6 - A violência e as religiões, contribuições para a paz; e o n. 58 - O sagrado na pessoa e na sociedade.

Analisaremos as revistas separadamente e buscaremos evidenciar quem escreve (grau e área de formação); o enfoque da abordagem, isto é, o modo como o tema é desenvolvido, seja a partir de uma religião, seja na perspectiva do Fenômeno Religioso; por fim verificaremos em qual dos cinco eixos temáticos propostos pelos PCNER o artigo se classifica. Essas categorias nos ajudarão a alcançar os objetivos propostos para a análise das revistas.

\section{a. Edição n. 6: A violência e as religiões, contribuições para a paz}

O tema da revista: A violência e as religiões, contribuições para a paz se propõe a "contribuir na busca de bases comuns para o diálogo inter-religioso" (DIÁLOGO, n.6, p. 1), como se afirmou no editorial da edição n. 6. Essa edição é do primeiro projeto gráfico, de modo que os textos são ilustrações com desenhos. Estes buscam destacar alguns elementos que mais são enfatizados no artigo. O tema geral é desdobrado em sete artigos, e a edição também traz mensagem, uma entrevista e notícias acerca do Ensino Religioso.

O primeiro artigo, A Torá promove a justiça e a paz, traz como articulista o rabino Henry Sobel (DIÁlOGO, n.6, p. 5-8), graduado em letras. Abordagem: Religiosa. O articulista, ao desenvolver o texto, se inclui neste, isto é, ele fala como um fiel ao usar a primeira pessoa do plural. Ao refletir acerca da violência, o autor afirma que "muitos conflitos no mundo de hoje são consequência da intolerância de um grupo em relação a outro" (DIÁLOGO, n.6, p. 7). O texto expressa a forma como o judaísmo interpreta a realidade de violência presente na sociedade, pois seu autor é um líder religioso que tem autoridade de falar em nome de sua tradição. Eixo temático: Ethos, pois apresenta a forma como o judaísmo lida com a violência.

$\mathrm{O}$ segundo artigo, As raízes não sacrificiais da mensagem cristã, é desenvolvido pelo docente e doutor em teologia Ênio José da Costa Brito (DIÁLOGO, n.6, p. 10-15). Abordagem: Religiosa. O texto busca estabelecer as relações entre violência e religiosidade, a partir do cristianismo, e se propõe a "resgatar o núcleo histórico das cristologias bíblicas neotestamentárias, isto é, resgatar delas a marca sacrificial tão presente na teoria e prática cristã" (DIÁLOGO, n.6, p. 11). O articulista evidencia elementos que o cristianismo assumiu a partir das atitudes de Jesus, como, por exemplo, "a construção de uma sociedade mais justa que inclua a todos. Uma sociedade que possa começar a reunir todos à mesa e celebrar o ano da graça" (DIÁLOGO, n.6, p. 15). Eixo temático: Teologias, pois a reflexão apresenta vários elementos constituintes do cristianismo.

O terceiro artigo, A violência e a paz: os ensinamentos de Buddha, é desenvolvido pelo doutor em etnologia Arthur Shaker Fauzi Eid (DIÁLOGO, n.6, p. 1823). Abordagem: Religiosa. Inicialmente o articulista contextualiza a origem de Buddha, para em seguida falar da existência da violência "que abala todos os seres, pois todos os seres prezam a vida e buscam a felicidade" (DIÁLOGO, n.6, p. 23). O artigo evidencia a visão budista acerca da elevação espiritual do ser humano, e o faz a partir das Quatro Nobres Verdades que compõem o budismo. Eixo temático: Teologias, por expor elementos fundamentais da tradição budista.

O quarto artigo, Tudo é espelho, e a vida do homem é sua autoexpressão, tem como articulista o mestre em Ciências da Religião Yumi Fujikura (DIÁLOGO, n.6, 
p. 24-28). Abordagem: Religiosa. O autor apresenta alguns "preceitos" que a Perfect Liberty propõe aos seus seguidores e que visa a ajudar não só a seus membros, mas à sociedade de modo geral, a enfrentar a questão da violência. No texto se afirma que, "procurando o caminho da paz e do amor entre as pessoas, o respeito à dignidade humana e a caridade fraterna haverá necessariamente a diminuição da violência e o aumento do respeito entre as pessoas" (DIÁLOGO, n.6, p. 27). Eixo temático: Culturas e Tradições Religiosas, por evidenciar as orientações religiosas e éticas da tradição Perfect Liberty.

O quinto artigo, A tradição de Òrìsà: nossa visão de um mundo mais alegre, é escrito pela sacerdotisa do Ilê Leuiwyato Sandra Medeiros Epega (DIÁLOGO, n.6, p. 30-34), da qual não identificamos a área e grau de formação. Abordagem: Religiosa. $\mathrm{O}$ artigo apresenta os orixás como aqueles que regem toda a existência, bem como a vida e a morte. Entretanto, nenhum orixá é responsável pela violência causada pelo ser humano, de modo que cabe a este ensinar aos seus descendentes a vivência dos valores e da religião, e isto se faz por meio da prática dos mesmos, pois "é mais fácil uma criança compartilhar que sobedecer" (DIÁLOGO, n.6, p. 34). Eixo temático: Culturas e Tradições Religiosas, por enfatizar elementos de matriz afro-brasileira.

O sexto artigo, Quando a violência esfria, a terra se alegra, é de autoria do mestre em teologia e pastor luterano Roberto Zwetsch (DIÁLOGO, n.6, p. 36-46). Abordagem: Religiosa. $\mathrm{O}$ texto trata da espiritualidade indígena e do modo como esta lida com a violência. $\mathrm{O}$ autor tem como ponto de referência uma experiência vivida entre os indígenas Kulina, e a pesquisa de outros estudiosos. Segundo o articulista, os indígenas compreendem que "o mal não é uma simples atitude moral negativa, mas uma condição que precisa ser abolida/vencida" (DIÁLOGO, n.6, p. 41). Embora o articulista não seja de tradição indígena, o artigo apresenta com clareza os princípios que regem a vida desses povos, seus costumes e a relação com o sagrado. Eixo temático: Culturas e Tradições Religiosas, por sua análise acerca da espiritualidade e cultura indígena.

O sétimo artigo, A televisão, a nova religião do mundo moderno, tem como articulista o doutor em comunicação Ismar de Oliveira Soares (DIÁLOGO, n.6, p. 4451). Abordagem: Fenomenológica. $O$ texto faz uma análise de como a televisão apresenta os elementos religiosos e culturais da sociedade brasileira. A cultura de massa funciona "como um rito coletivo", no qual a "religião não somente está presente nos meios de comunicação, mas que acaba por se transformar em espaço de seu exercício, sempre, nos mesmos horários, abertos ao permanente novo" (DIÁLOGO, n.6, p. 51). Eixo temático: Ethos, pelo fato de apontar para a necessidade de uma visão crítica diante do conteúdo que é apresentado pelas TVs.

Os sete artigos da edição n. 6 foram classificados conforme os eixos temáticos: dois em Ethos; dois em Teologias; e três em Culturas e Tradições Religiosas. Acerca dos temas desenvolvidos, os seis artigos foram apresentados na perspectiva de uma tradição religiosa específica, e apenas um foi desenvolvido a partir do Fenômeno Religioso. É interessante ressaltar que alguns articulistas que escrevem a respeito das tradições religiosas não são apenas estudiosos, mas podem ser considerados "fiéis", pois algumas vezes se incluem no texto ou se identificam como tal nos créditos do artigo. Grosso modo, os enfoques correspondem ao que é proposto no título do artigo e são consonantes com o tema da edição.

\section{b. Edição n. 58: O sagrado na pessoa e na sociedade}


A última revista Diálogo a ser analisada é a edição n. 58, cujo tema é $O$ sagrado na pessoa e na sociedade. Além das ilustrações, a revista também traz um boxe com outras informações que não estão no artigo. Essa edição da Diálogo apresenta seis artigos e oito seções que complementam a proposta do tema geral, além de conto, dicas de leitura, resenha e sugestão de atividade.

O primeiro artigo, O Sagrado e a religiosidade como jornada psíquica, tem como articulista o doutor em filosofia Marcos Ferreira Santos (DIÁLOGO, n. 58, p. 8-13). Abordagem: Fenomenológica. O autor propõe uma reflexão acerca da relação humana com o sagrado. Ele constata que no campo da psicologia as posições frente à questão religiosa são diversas, pois "trata-se de uma intensa e extensa jornada existencial e psíquica para uma possível plenitude" (DIÁLOGO, n. 58, p. 11). Eixo temático: Ethos, pelo caráter analítico-subjetivo do texto.

$\mathrm{O}$ segundo artigo, A transcendência humana e o sagrado, tem como articulista o doutorando em teologia Marlon Leandro Schock (DIÁLOGO, n. 58, p. 1418). Abordagem: Fenomenológica. Segundo o autor, o ser humano traz consigo a capacidade de transcender, pois "nós, seres humanos, mantemos uma atitude de perplexidade e esperanças simultâneas, abertos a toda realidade possível" (DIÁLOGO, n. 58, p. 16). O articulista também busca estabelecer algumas distinções teóricas entre transcendência e sagrado. Eixo temático: Culturas e Tradições Religiosas, por sua leitura acerca da transcendência.

O terceiro artigo, Religião e Ciência: experimentações, tem como articulista a doutora em sociologia Leila Marrach Bastos de Albuquerque (DIÁLOGO, n. 58, p. 20-23). Abordagem: Fenomenológica. O texto analisa a relação entre Ciência e Religião no contexto da modernidade. Segundo a autora, "tanto a Religião como a Ciência são interpretações do mundo, que orientam os modos de agir, sentir e pensar das pessoas coletivamente" (DIÁLOGO, n. 58, p. 20). Constata-se um intercâmbio de linguagem e de "valores" entre Religião e Ciência. Eixo temático: Culturas e Tradições Religiosas, por apontar o desenvolvimento dialógico entre Religião e Ciência.

O quarto artigo, $O$ Bricoleur sagrado contemporâneo, tem como articulista o mestre em sociologia Aislan Vieira de Melo (DIÁlOGO, n. 58, p. 24-29). Abordagem: Fenomenológica. $\mathrm{O}$ autor, ao analisar a questão do sagrado, afirma que "o sistema religioso, mesmo não conservando o caráter hegemônico de antes, mantém forte influência na conduta do indivíduo" (DIÁLOGO, n. 58, p. 25). Este, ao transitar entre as religiões, faz surgir uma expressão das práticas religiosas que o articulista chamou de bricoleur. O trânsito religioso faz com que as pessoas levem consigo alguns elementos da tradição anterior, e, ao mesmo tempo, agreguem a estes novas práticas. Eixo temático: Culturas e Tradições Religiosas, por sua análise acerca da prática religiosa atual.

O quinto artigo, $O$ sagrado como sentido transformador, tem como articulista o mestre em sociologia Cléber Seixas Guimarães (DIÁLOGO, n. 58, p. 3035). Abordagem: Fenomenológica. $\mathrm{O}$ autor analisa um caso específico da Igreja do Evangelho Quadrangular e suas transformações e adequações na sociedade contemporânea. Segundo o articulista, a IEQ buscou agregar "elementos mágicos que servem de pontes entre o indivíduo e seu Deus" (DIÁLOGO, n. 58, p. 31). O texto também evidencia as relações entre a instituição religiosa e seus fieis, e a experiência religiosa que esta realiza em seus cultos. Eixo temático: Culturas e Tradições Religiosas, por sua análise de uma instituição específica. 
O sexto artigo, $O$ imaginário ribeirinho e a relação com o sobrenatural, tem como articulista a doutora em linguística Nair Ferreira Gurgel do Amaral (DIÁLOGO, n. 58, p. 36-41). Abordagem: Fenomenológica. O texto analisa a crença nos mitos e lendas amazônicas que a população ribeirinha dessa região cultiva e transmite de uma geração a outra com certa "sacralidade". A autora afirma que "mito e lenda retratam necessidades humanas de entender as coisas do universo e de superar o medo e a insegurança" (DIÁLOGO, n. 58, p. 37). Eixo temático: Culturas e Tradições Religiosas, por sua análise cultural do contexto amazônico.

Falar do sagrado certamente não é um tema fácil, ainda mais num curto espaço de uma revista. Embora os temas tenham cercado a questão de forma tangencial, a revista consegue responder à temática da capa nos artigos acerca do imaginário ribeirinho, do bricoleur religioso da atualidade e na questão psíquica da religiosidade. Em relação aos eixos temáticos, sobressaíram o de Culturas e Tradições Religiosas, com cinco artigos e Ethos com um artigo. Os demais eixos não foram abordados.

\section{Conclusão}

Ao analisarmos a caminhada do Ensino Religioso constatamos que os diferentes modos de conceber o seu conteúdo sempre esteve marcado pelo seu caráter ambivalente, sendo concebido ora como catequese, ora como estudo do Fenômeno Religioso. De tal ambivalência originaram-se diferentes posicionamentos em relação à presença do Ensino Religioso no âmbito escolar.

Em sintonia com essa trajetória do Ensino Religioso, nasceu a revista

Diálogo, cuja ideia surgiu em resposta à solicitação dos professores que participaram do $10^{\circ}$ Ener, realizado em agosto de 1994, na cidade de Fortaleza (CE), os quais

manifestaram o desejo de ter uma revista que fosse um meio de comunicação, formação e troca de experiência entre eles. Em atenção a esse desejo, a Paulinas Editora lançou em setembro de 1995 o primeiro número da Diálogo - Revista de Ensino Religioso. E, desde o seu lançamento, a revista buscou contribuir para o desenvolvimento do Ensino Religioso, através de suas abordagens à luz das diversas áreas do conhecimento e em particular das Ciências da Religião.

Compreendemos que de modo geral, quando falamos de Ensino Religioso, não estamos nos referindo apenas a um modelo ou forma de desenvolver o conteúdo dessa disciplina. Cada modelo de Ensino Religioso teve e/ou tem sua validade, e corresponde a um determinado contexto socioeducacional, de modo que ao se analisar ou mesmo lançar criticas a alguns dos modelos, é necessário considerar seu contexto, a fim de se evitar leituras equivocadas e análises reducionistas.

No sentido de demonstrar, que é possível a proposta de um modelo de Ensino Religioso na perspectiva das Ciências da Religião, analisamos a perspectiva e o conteúdo da revista Diálogo. Ao examinamos a revista, percebemos que suas abordagens tratam dos temas na perspectiva das diferentes áreas de conhecimento, tais como a Sociologia, a Antropologia, a Filosofia e a Teologia, entre outras. Tal característica confirma que a proposta dos PCNER sistematiza os conteúdos do Ensino Religioso nos cinco eixos temáticos e que abrem a perspectiva de um Ensino Religioso 
no modelo das Ciências da Religião, pois ao tratarmos desse componente curricular, devemos lembrar que temos diante de nós algo que é de da educação, e como tal tem uma realidade plural e diversa no Brasil. é dentro desse domínio que ela deve ser compreendida e não no âmbito de uma religião em particular.

Quando analisamos alguns números da revista, percebemos dois tipos de abordagens: a fenomenológica e a religiosa. Apesar de nossa análise ser apenas de dois exemplares aleatórios, uma vez não nos seria possível analisarmos a todas as edições da revista, podemos concluir que textos com enfoque no Fenômeno Religioso são mais frequentes entre os artigos. Isso demonstra que a perspectiva de Ensino Religioso presente na revista se coaduna com o modelo das Ciências da Religião. Outro aspecto relevante é que, embora a quantidade dos artigos com abordagem acerca da religião seja menor, fica evidente que é possível apresentar as religiões sem proselitismo através de perspectiva que se baseia nas diferentes áreas de conhecimento. Tais abordagens contribuem com uma cosmovisão transreligiosa e com a educação do cidadão segundo o Ensino Religioso, no modelo das Ciências da Religião.

\section{Referenciais}

CÂNDIDO, Viviane Cristina. O Ensino Religioso em suas fontes. Uma contribuição para a epistemologia do Ensino Religioso. 2004. Dissertação (Mestrado em Ciências da Religião) - Centro Universitário Nove de Julho, São Paulo (SP), 2004.

CONFERÊNCIA NACIONAL DOS BISPOS DO BRASIL. A caminhada do Ensino Religioso na CNBB. 1999, (Mimeo)

DIÁLOGO - REVISTA DE ENSINO RELIGIOSO.

FONAPER. Parâmetros curriculares nacionais: Ensino Religioso. São Paulo: AveMaria, 1997.

GRESCHAT, Hans-Jürgen. O que é ciência da religião? São Paulo: Paulinas, 2006.

GRUEN, Wolfgang. O ensino religioso na escola. Petrópolis: Vozes, 1995.

JUNQUEIRA, Sérgio Rogério Azevedo. O processo de escolarização do ensino religioso no Brasil. 2000. Tese (Doutorado em Educação). Universidade Pontifícia Salesiana, Roma, 2000.

KRONBAUER, Selenir Corrêa Gonçalvez; SIMIONATO, Margereth Fadanelli (orgs.). Articulando saberes na formação de professores. São Paulo: Paulinas, 2012.

OLIVEIRA, Lilian Blanck de. Formação de docentes para o ensino religioso: perspectivas e impulsos a partir da ética social de Martinho Lutero. 2003. Tese (Doutorado em Teologia). Escola Superior de Teologia, São Leopoldo (RS), 2003. 
PASSOS, João Décio. Ensino Religioso: construção de uma proposta. São Paulo: Paulinas, 2007.

Epistemologia do Ensino Religioso: a inconveniência política de uma área de conhecimento. In: Ciberteologia - Revista de Teologia \& Cultura, São Paulo: Paulinas, Ano VII, n. 34, Abril/Maio/Junho, p. 108-124, 2011.

SENA, Luzia (org.). Ensino Religioso e formação docente; ciências da religião e ensino religioso em diálogo. São Paulo: Paulinas, 2006.

SOARES, Afonso Maria Ligorio. Religião \& educação: da ciência da religião ao Ensino Religioso. São Paulo: Paulinas, 2010.

Recebido: 08/03/2013

Received: 03/08/2013

Aprovado: 04/07/2013

Approved: 07/04/2013 